\title{
Retrospective and statistical study of pattern of acute poisoning among cases presented to emergency department of Kafr EI - sheikh Governorate hospitals
}

\author{
Mohamed A. El Gendy, Nagy Alfadaly, Ibrahim N. Mohamed \\ Forensic Medicine and Clinical Toxicology Department, Faculty of Medicine, Al -Azhar University, \\ Cairo, Egypt \\ Corresponding author: Mohamed A. El Gendy,email:yzezogindy@gmail.com
}

\begin{abstract}
Background: Acute poisoning is a common situation in emergency departments all over the world. It may cause severe complications and death. Treatment of these cases requires great medical care and significant costs. There are many differences with respect to the pattern and cause of acute poisoning between geographical regions, even within the same country.

Objective: This study was carried out to assess the pattern of acute poisoning with drugs, chemicals and natural toxins in both adults and children in Kafr El - Sheikh Governorate hospitals.

Methods: The study was conducted onacutely intoxicated cases admitted to some of Kafr El - Sheikh Governorate hospitals. The medical records of cases who were admitted due to acute poisoning from January 2015 to January 2017 were reviewed retrospectively.

Results: This study included 1046 acute poisoned cases presented to ED. There were 85\% less than 6 years old and $15 \%$ more than 12 years old. .Number of males with toxic exposure was 421 while that of females was 625. Pharmacological agents, constituted the highest percentage of the poisoning (28.92\%), followed by Insecticides $(24.4 \%)$, household products $(20.45 \%)$, food poisoning $(12.5 \%)$ and animal poisoning $(8.03 \%)$.The majority of cases of acute poisoning were accidental $(78.01 \%)$, followed by attempted suicide (21.98\%). The majority of cases stayed at the hospital (51.9\%), while $(40.8 \%)$ Discharged from ED and about (7.2\%) referred to nearest poison centers. 1027 patients (98.18\%) recovered, only $1.3 \%$ developed complications.

Conclusion: Accidental poisoning is still a significant cause of morbidity. Regarding the high prevalenceofpharmaceuticaldrugandhouseholdproductspoisoninginchildren, implementation of legislations to ban over the counter selling of medications and to sell potentially dangerous chemicals in childproof containers is recommended. Improving proper and complete medical record-keeping is also suggested for a better information access.
\end{abstract}

Keywords: Acute Poisoning, Drugs, Household Products, Animal Envenomation

\section{Introduction}

Poisoning is the occurrence of harmful effects due to exposure to a foreign chemical or a xenobiotic (1). Xenobiotic is a chemical compound foreign to a given biological system. With respect to animals and humans, xenobiotic include drugs, drug metabolites, and environmental compounds such as pollutants that are not produced by the body. In the environment, xenobiotic include synthetic pesticides, herbicides and industrial pollutants that would not be found in nature ${ }^{(2)}$.

Poisoning cases are increasing day by day due to changes in the life style and social behavior. Advances in technology and social development have resulted in the availability of most drugs and chemical substances in the community $^{(3)}$.

Natural compounds can also become xenobiotic if they are taken up by another organism, such as the uptake of natural human hormones by fish found downstream of sewage treatment plant outfalls, or the chemical defenses produced by some organisms as protection against predators. Xenobiotic can produce harm to the biological $\operatorname{organism}^{(4)}$.

The developed world has accurate information on incidence and changing trends of causative agents as a result of rigorous population census and mortality data and the development of Poison Control Center (PCC) ${ }^{(5)}$. To the best of our knowledge, till date, no study on acute poisoning in Kafr El Sheikh Governorate region has been published. Kafr El Sheikh is a governorate that has an area of $3,437 \mathrm{~km}^{2}$. It islocated in the northern part ofEgypt, along the western branch of the Nile in the Delta. The population of the governorate as a whole is approximately $3,172,753$. 


\section{Subjects and methods}

This is a cross-sectional retrospective and statistical study and the data were collected from the medical files of the routinely registered data during attendance of acutely poisoned cases presented to some hospitals in Kafr El-Sheikh Governorate (Kafr El- Sheikh general hospital - Al obour Insurance hospital) fromJanuary $1^{\text {st }} 2015$ to January $1^{\text {st }} 2017$. The study was approved by the Ethics Board of Al-Azhar University.

\section{The data which werecollected included:}

\section{I- Epidemiological analysis(Patient's} residence, age, sex, marital status, time interval between the incidence of acute poisoning and hospitalization,duration of hospitalization i.e. hospital stay).

II- Medico legal analysis (route of administration, type, manner and symptoms of poisoning ,sex distribution, seasonal variation,clinical manifestations, received medical management and final outcome).

- The diagnosis of poisoning was based on the history given by the patients or their relatives and clinical examination.
- All the necessary laboratory and confirmatory tests which performed to confirm the diagnosis of poisoning (if available).

\section{Inclusion criteria}

All the suspected acute poisoning cases admitted to Kafr El- Sheikh Governorate hospitals will be include in this study.

\section{Exclusion criteria}

All cases with allergic reactions to drugs and Patients with co-morbid conditions including metabolic causes and structural brain related causes were excluded.

\section{Results}

The total number of cases in the present study were 1046 cases presented to emergency department (ED) of Kafr El-Sheikh Governorate hospitals suffering from acute poisoning. There were 864 cases from Kafr ElSheikh general hospital and 182 cases from Al Obour health insurance hospital, (704) of study cases were below 12 year (pediatric group) and (342) were above 12 years (adolescent $\&$ adult group).

Table (1): Distribution ofthestudied cases according to hospitalof admission in relation to sex and age grouping

\begin{tabular}{|l|l|l|l|l|l|l|}
\hline \multirow{2}{*}{ Hospitals } & \multicolumn{2}{|l|}{ Pediatrics group } & \multicolumn{2}{l|}{ Adolescent \& adult Groups } & Total & $\%$ \\
\cline { 2 - 7 } & Males & females & Males & Females & N & \\
\hline $\begin{array}{l}\text { Kafr El-Sheikh general } \\
\text { hospital }\end{array}$ & 212 & 397 & 94 & 161 & 864 & 82.6 \\
\hline $\begin{array}{l}\text { Al Obour health } \\
\text { insurance hospital }\end{array}$ & 56 & 39 & 59 & 28 & 182 & 17.4 \\
\hline
\end{tabular}

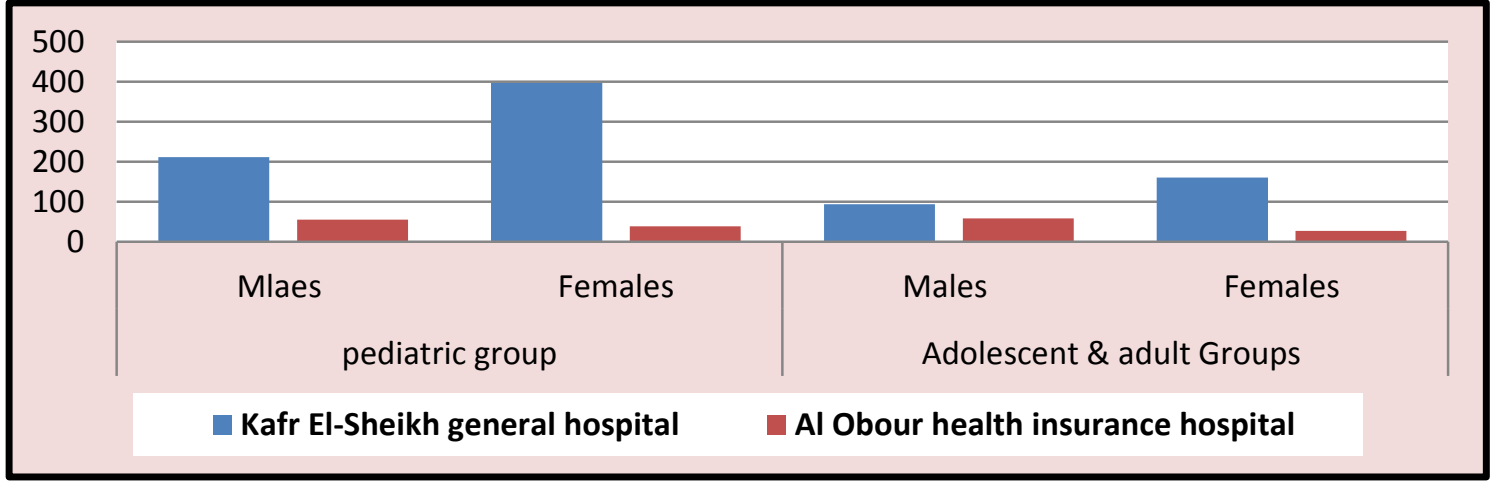

Figure (1): Distribution of cases according to hospital of admission in relation to sex. 
Table (2): Distribution of acute intoxicated cases according to Age grouping:

\begin{tabular}{|c|c|c|c|c|c|}
\hline \multirow[t]{2}{*}{ Group } & \multirow{2}{*}{$\begin{array}{l}\text { Group } \\
\text { Age group }\end{array}$} & \multicolumn{2}{|c|}{ Studied cases } & \multirow[t]{2}{*}{ Test } & \multirow[t]{2}{*}{ P-value } \\
\hline & & $\mathrm{n}$. & $\%$ & & \\
\hline \multirow[t]{2}{*}{ Pediatric group } & Group 1 (1-6 y) & 463 & 44.26 & \multirow{6}{*}{1.10} & \multirow{6}{*}{$\begin{array}{l}0.77 \\
(\mathrm{NS})\end{array}$} \\
\hline & Group 2 (7-12 Y) & 241 & 23 & & \\
\hline \multirow{4}{*}{$\begin{array}{ll}\text { Adolescent } & \& \\
\text { adult group } & \end{array}$} & Group 3 (13-18y) & 187 & 17.87 & & \\
\hline & Group 4 (19-30 y) & 88 & 8.41 & & \\
\hline & Group 5 ( above 30 y) & 67 & 6.40 & & \\
\hline & Total & 1046 & 100.0 & & \\
\hline
\end{tabular}

[N.B]: (NS): Meansnon-significant.

Age grouping: There were (704) case below 12 year (pediatric group), (463) of them from 1 to 6 year and other (241) case were from 7 to 12 year. And (342) above 12 year (adolescent \& adult group), (187) of them were from 13-18 year, (88) case were from 19- 30 year, finally (67) case were above 30 year.

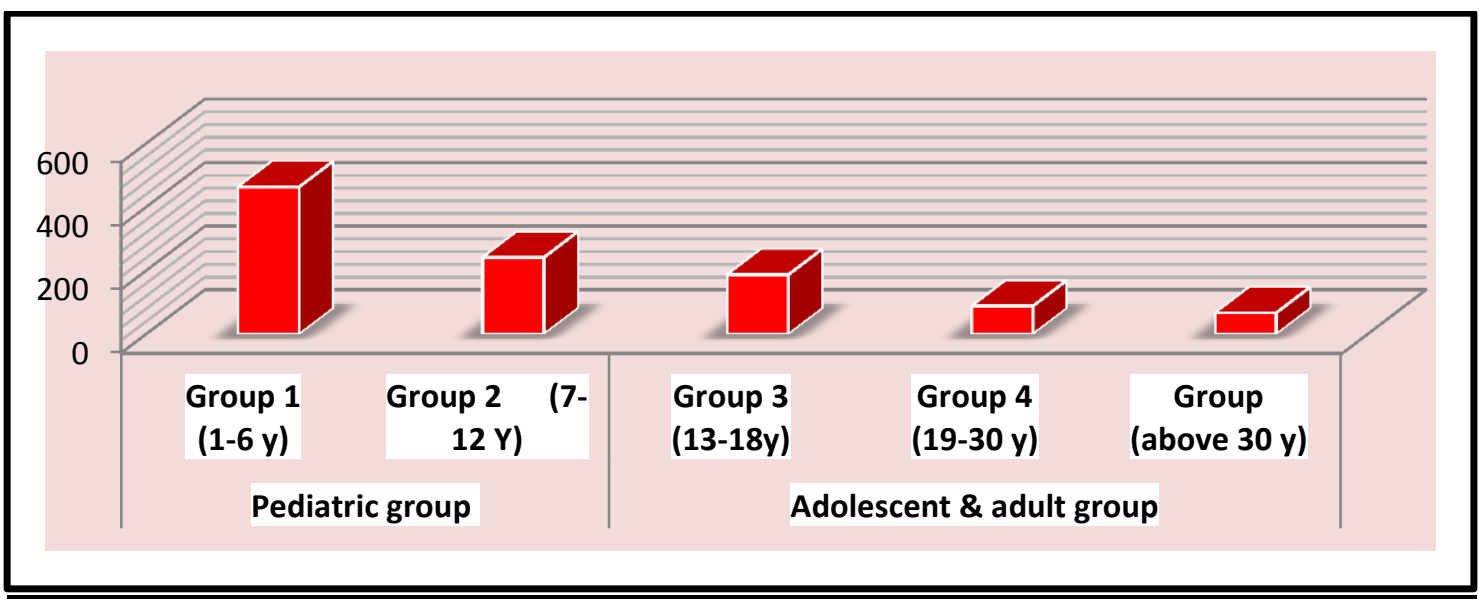

Figure ( 2): Distribution of patients with acute poisoning according to the age groups Sex distribution:

In the present study, there was female predominance in the first group (aged 1-6 years); while in the subsequent groups there was male predominance (table 2).

Table (3): Sex distribution among studied groups:

\begin{tabular}{|l|l|l|l|l|l|l|}
\hline \multirow{2}{*}{ sex } & \multicolumn{2}{l|}{ Pediatrics group } & \multicolumn{2}{l|}{ Adolescent \& adult Group } & \multicolumn{2}{l|}{ Total } \\
\cline { 2 - 7 } & $\mathrm{N}$ & $\%$ & $\mathrm{~N}$ & $\%$ & $\mathrm{~N}$ & $\%$ \\
\hline Male & $\mathbf{2 6 8}$ & $\mathbf{2 5 . 6}$ & $\mathbf{1 8 9}$ & $\mathbf{1 0 . 6}$ & $\mathbf{4 2 1}$ & $\mathbf{4 0 . 1 5}$ \\
\hline Female & $\mathbf{4 3 6}$ & $\mathbf{4 1 . 6}$ & $\mathbf{1 5 3}$ & $\mathbf{1 8 . 0 6}$ & $\mathbf{6 2 5}$ & $\mathbf{5 9 . 8 4}$ \\
\hline Statistics & $\mathrm{X}^{2}=0.85, \mathrm{p}=0.35(\mathrm{~ns})$ & \multicolumn{3}{|l}{} \\
\hline
\end{tabular}

\section{Toxic agents:}

Pharmacological agents, constituted the highest percentage of the poisoning (28.92\%), followed by Insecticides $(24.4 \%)$, household products $(20.45 \%)$, food poisoning $(12.5 \%)$ and animal poisoning $(8.03 \%)$. 
Table (4):Distribution of toxic agents among studied cases:

\begin{tabular}{|l|l|l|l|l|}
\hline \multirow{2}{*}{ pharmacological } & Pediatrics group & Adolescent \& adult Group & \multicolumn{2}{l|}{ Total } \\
\cline { 2 - 5 } & $\mathbf{N}$ & $\mathbf{N}$ & 111 & $\mathbf{N}$ \\
\hline Insecticides & 179 & 67 & 290 & 28.92 \\
\hline Household product & 203 & 11 & 256 & 24.4 \\
\hline food poisoning & 73 & 58 & 214 & 20.45 \\
\hline Animal poisoning & 19 & 69 & 83 & 12.5 \\
\hline unknown cause & 41 & 26 & 67 & 8.03 \\
\hline Statistics & $\mathrm{X}^{2}=8.78, \mathrm{p}=0.45(\mathrm{~ns})$ & & & 5.92 \\
\hline
\end{tabular}

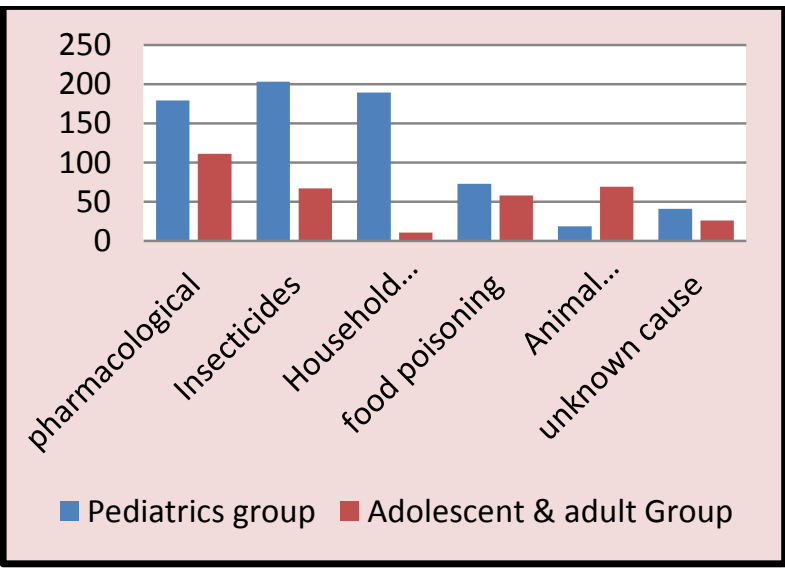

Fig (3): Distribution of patients with acute poisoning according to sex

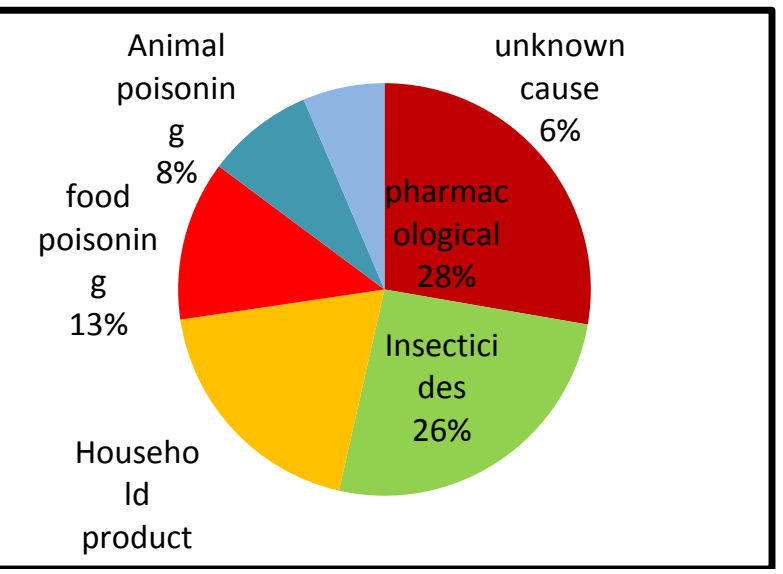

Figure (4)Toxic agent distribution to according intoxicated cases

\section{Toxic agent to sex:}

Female cases below 12 years represent the highest percentage in toxicity by pharmacological, insecticides and household products than males $(9.7 \%, 14.1 \%$ and $11.5 \%)$ respectively.

Adult males represent the highest percentage in animal toxicity (4.3\%) than female cases $(2.1 \%)$.

Table (5): Comparison between pediatric male - female patients and adolescent and adult malefemale according to the type of poison:

\begin{tabular}{|l|l|l|l|l|l|l|l|l|}
\hline & \multicolumn{4}{|l|}{ Pediatrics group } & \multicolumn{3}{l|}{ Adolescent \& adult Group } \\
\cline { 2 - 10 } & Male & $\%$ & Female & $\%$ & Male & $\%$ & Female & $\%$ \\
\hline pharmacological & 77 & 7.3 & 102 & 9.7 & 36 & 3.4 & 75 & 7.17 \\
\hline Insecticides & 68 & 5.2 & 121 & 14.1 & 28 & 2.6 & 39 & 3.7 \\
\hline Household product & 55 & 5.6 & 148 & 11.5 & 6 & 0.5 & 5 & 0.47 \\
\hline food poisoning & 31 & 2.9 & 42 & 4.01 & 27 & 2.5 & 31 & 2.9 \\
\hline Animal poisoning & 15 & 1.4 & 4 & 0.38 & 46 & 4.3 & 23 & 2.1 \\
\hline unknown cause & 22 & 2.1 & 19 & 1.8 & 10 & 0.9 & 16 & 1.5 \\
\hline Statistics & $\mathrm{X}^{2}=9.74, \mathrm{p}=0.021$ \\
\hline
\end{tabular}




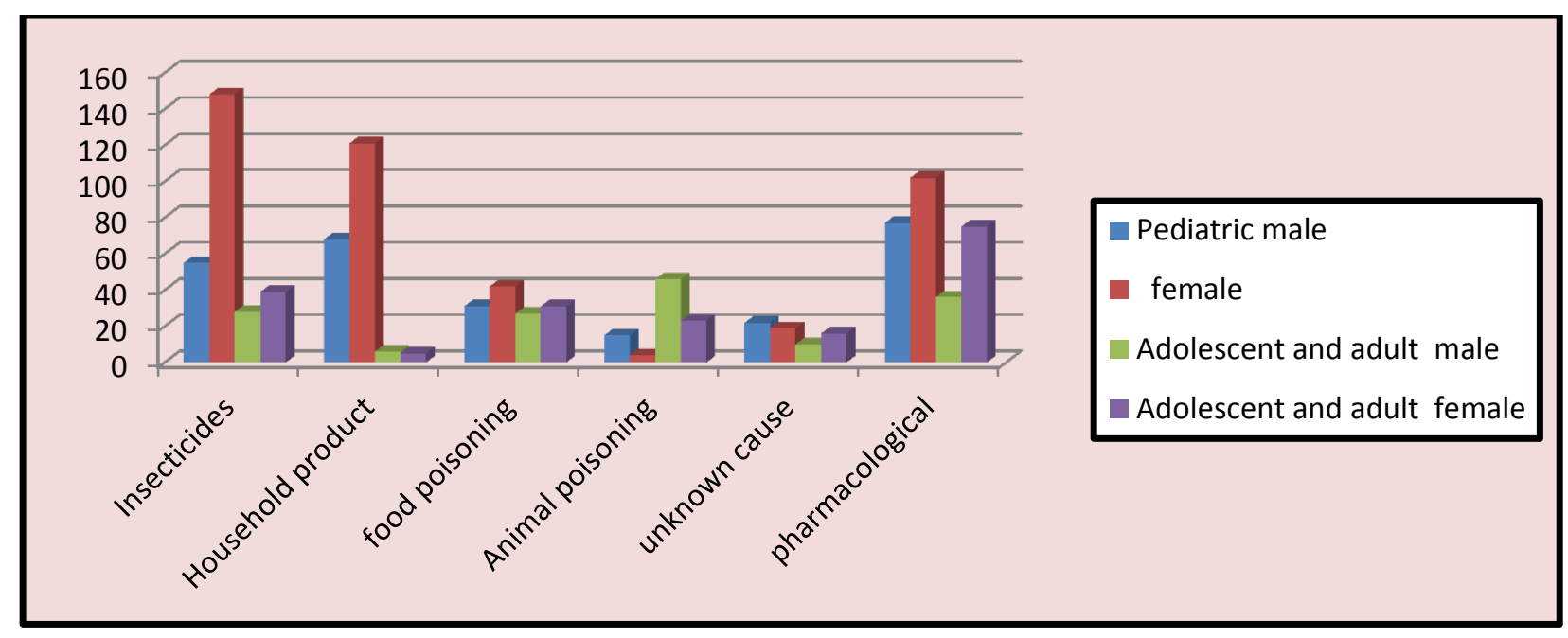

Fig (5): Distribution of cases according to toxic agent in relation to sex .

\section{According to time:}

\section{Month of admission in relation to age grouping :}

When considering the month of intoxication, we found that, the higher incidence was in August (157 case $15 \%$ ) then July (137 case; $13.09 \%$ ) while the least incidence was in December (39 case; $3.7 \%$ ) and there was statistically significant difference between studied groups.

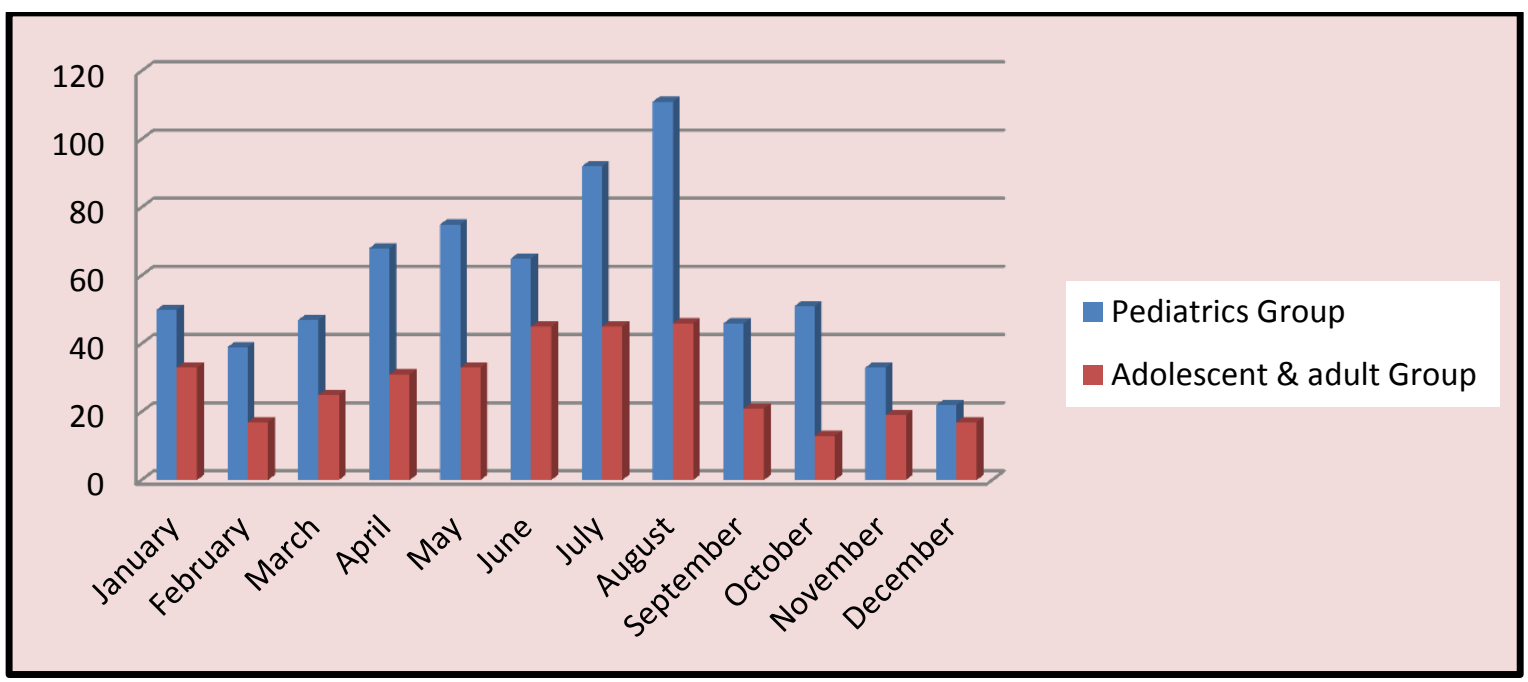

\section{Fig (6): Distribution of cases according to month of admission}

\section{- Season}

The rate of poisoning was higher in summer $(38.8 \%)$ then spring $(26.6 \%)$ followed by autumn $(17.7$ $\%)$ and finally winter (17\%). 
Table (6): Distribution of poisoned cases according to Season of admission:

\begin{tabular}{|l|l|l|l|l|}
\hline Season & $\begin{array}{l}\text { Pediatric Group } \\
(\mathbf{1}-\mathbf{1 2 Y})\end{array}$ & $\begin{array}{l}\text { Adolescent \& adult Group } \\
\text { (Above 12 Y) }\end{array}$ & Total & \% \\
\cline { 2 - 5 } & $\mathbf{N}$ & $\mathbf{N}$ & $\mathbf{N}$ & $\mathbf{\%}$ \\
\hline Winter & 111 & 67 & 178 & 17 \\
\hline Spring & 190 & 89 & 279 & 26.6 \\
\hline Summer & 273 & 133 & 406 & 38.8 \\
\hline Autumn & 130 & 53 & 183 & 17.7 \\
\hline
\end{tabular}
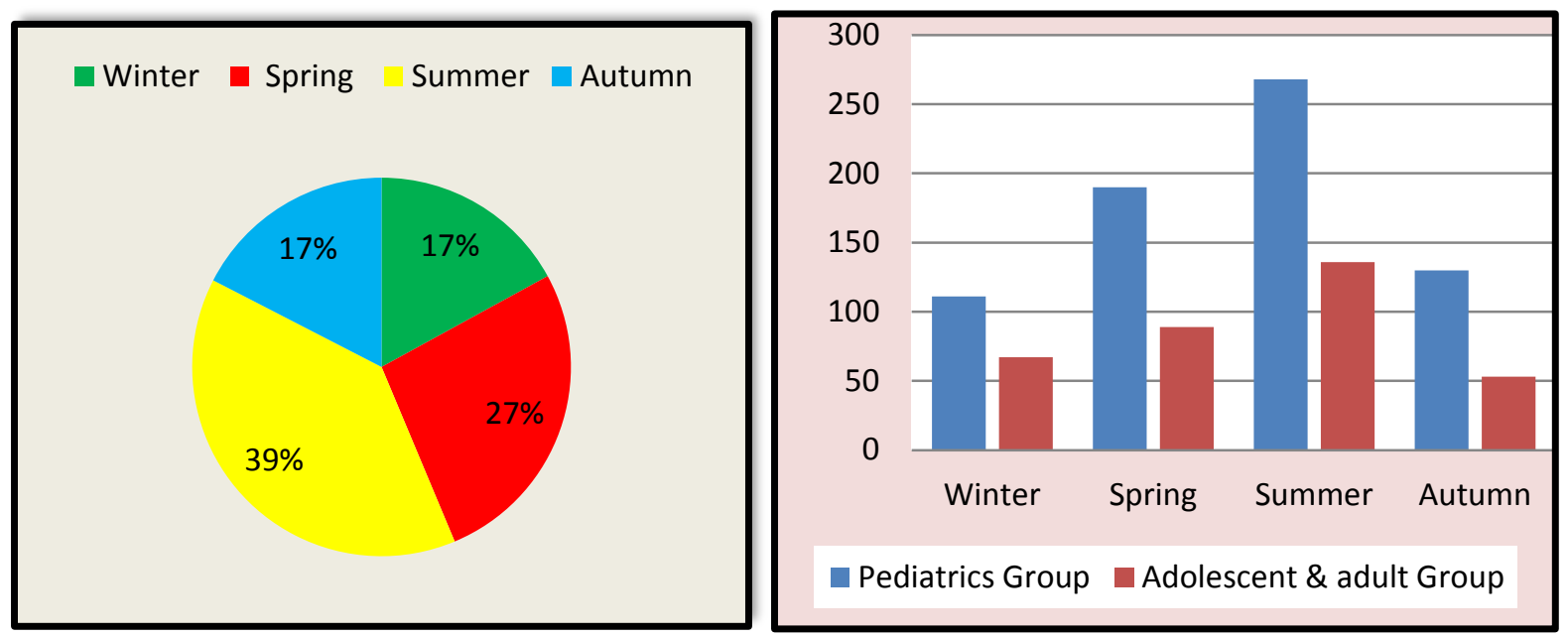

Fig (7):Seasonal variation among studied cases

\section{Manner of intoxication}

As regard to mode of intoxication, it was accidental in the majority of studied groups (816 case; $78.01 \%)$ and suicidal in 230 case (21.98\%) and there was statistically significant increase of accidental routes in pediatric groups when compared to adolescent and adult group.

Table (7): Distribution of studied cases according to manner of intoxication:

\begin{tabular}{|l|l|l|l|l|}
\hline \multirow{2}{*}{$\begin{array}{l}\text { Manner } \\
\text { intoxication }\end{array}$} & Pediatric group & Adolescent \& adult Group & Total \\
\cline { 2 - 5 } & $\mathrm{N}$ & $\mathrm{N}$ & $\mathrm{N}$ & $\%$ \\
\hline Accidental & 702 & 114 & 816 & 78.01 \\
\hline Suicidal & 2 & 228 & $\mathbf{2 3 0}$ & 21.98 \\
\hline Statistics & $\mathrm{X}^{2}=38.67, \mathrm{p}<0.001$ & & \\
\hline
\end{tabular}


Retrospective and statistical study of pattern....

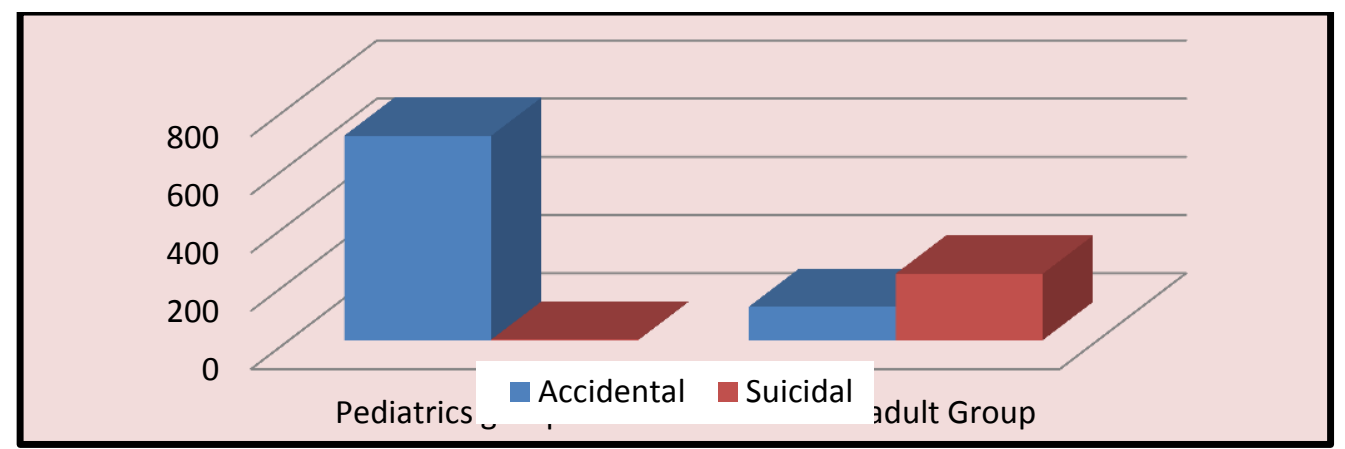

Fig (8): Manner of intoxication among studied cases .

\section{Route of intoxication:}

As regard to route of intoxication in studied children; the majority was oral route (912 case; $87.18 \%$ ) and other routes (e.g., skin, respiratory) in 134 case $(12.8 \%)$ and there was statistically significant difference between studied groups.

Table (8): Distribution of patients according to route of intoxication in studied case :

\begin{tabular}{|l|l|l|l|l|}
\hline \multirow{2}{*}{$\begin{array}{l}\text { Route of } \\
\text { intoxication }\end{array}$} & Pediatric group & Adolescent \& adult Group & \multicolumn{2}{|l|}{ Total } \\
\cline { 2 - 5 } & $\mathbf{N}$ & $\mathbf{N}$ & $\mathbf{N}$ & $\%$ \\
\hline Oral & 681 & 231 & 912 & 87.18 \\
\hline $\begin{array}{l}\text { Inhalation } \\
\text { (respiratory ) }\end{array}$ & 16 & 13 & 29 & 2.77 \\
\hline Others (e.g. skin) & 7 & 98 & 105 & 10.03 \\
\hline Statistics & $\mathrm{X}^{2}=16.71, \mathrm{p}=0.001$ & & \\
\hline
\end{tabular}

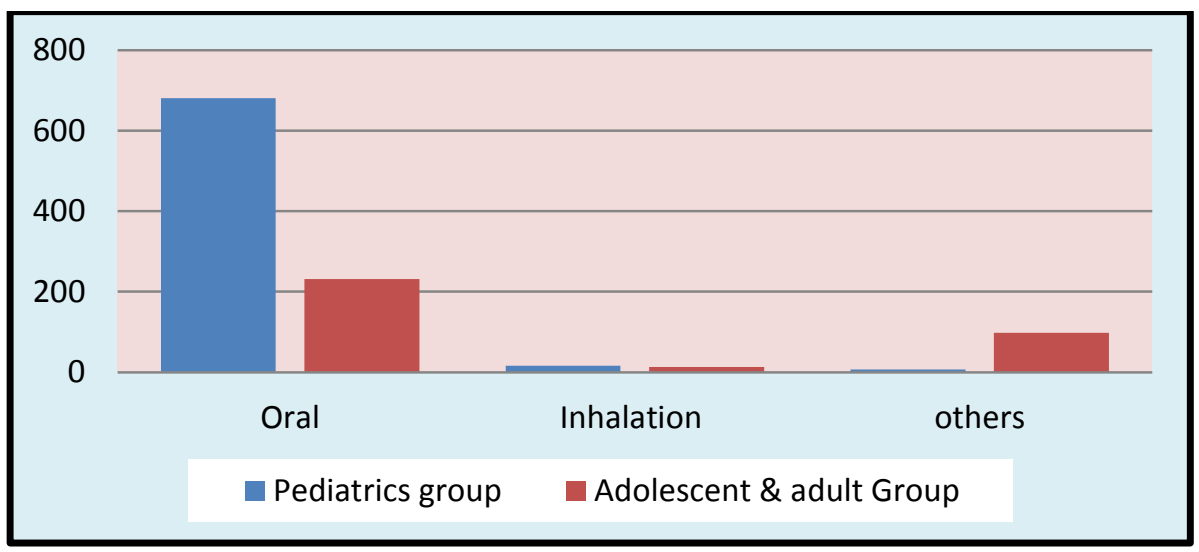

Figure (9) Distribution of studied cases according to route of intoxication

\section{Residence :}

In the present study, there was statistically significant difference between study groups as regard to residence (68.64\% rural and $31.35 \%$ urban areas).

Table (9): Distribution of studied cases as regard to residence

\begin{tabular}{|l|l|l|l|l|}
\hline \multirow{2}{*}{ Residence } & Pediatric group & $\begin{array}{l}\text { Adolescent \& adult } \\
\text { Groups }\end{array}$ & Total & \multicolumn{2}{l|}{} \\
\cline { 2 - 5 } & $\mathrm{N}$ & $\mathrm{N}$ & $\mathrm{N}$ & 68.64 \\
\hline Rural & 495 & 223 & 718 & 31.35 \\
\hline Urban & 209 & 119 & 328 & \\
\hline Statistics & $\mathrm{X}^{2}=5.93, \mathrm{p}=0.12(\mathrm{~ns})$ & & \\
\hline
\end{tabular}




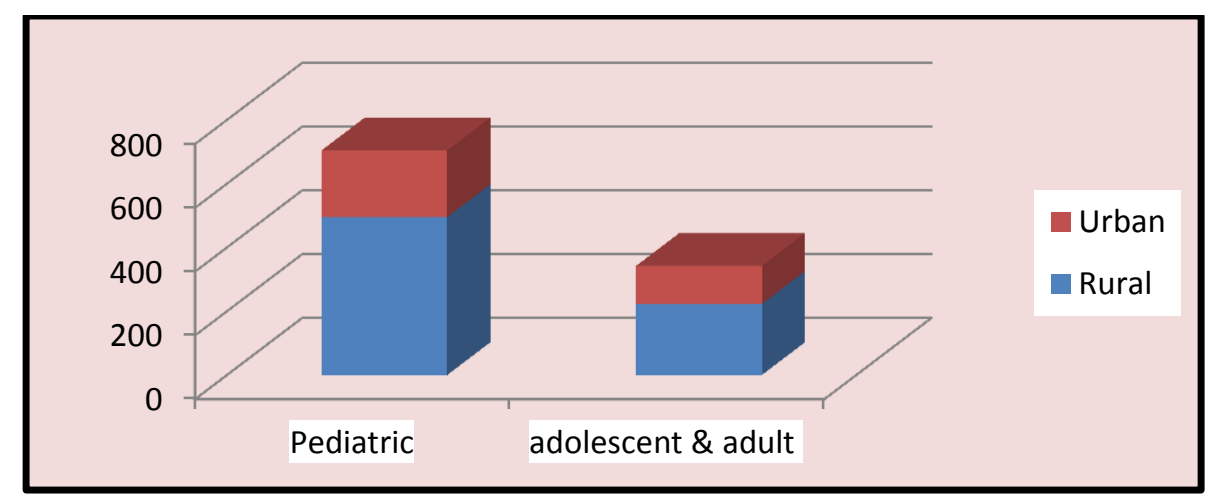

Figure (10) : Distribution of cases with acute poisoning according to residency

\section{Outcome}

-The majority of cases recovered in all age groups, only 14 case showed complications.

-In the present study only 5 cases died with mortality rate $(0.47 \%)$.

Table 5: Distribution of patients as regard to outcome in relation to age grouping

\begin{tabular}{|l|l|l|l|l|}
\hline \multirow{2}{*}{ Outcome } & $\begin{array}{l}\text { Pediatrics } \\
\text { group }\end{array}$ & $\begin{array}{l}\text { Adolescent \& } \\
\text { adult Group }\end{array}$ & \multicolumn{2}{|l|}{ Total } \\
\cline { 2 - 5 } & $\mathrm{N}$ & $\mathrm{N}$ & $\mathrm{N}$ & $\%$ \\
\hline $\begin{array}{l}\text { Complete } \\
\text { recovery }\end{array}$ & 692 & 335 & 1027 & 98.18 \\
\hline Complication & 9 & 5 & 14 & 1.3 \\
\hline Death & 3 & 2 & 5 & 0.47 \\
\hline Statistics & \multicolumn{4}{|l|}{} \\
\hline
\end{tabular}

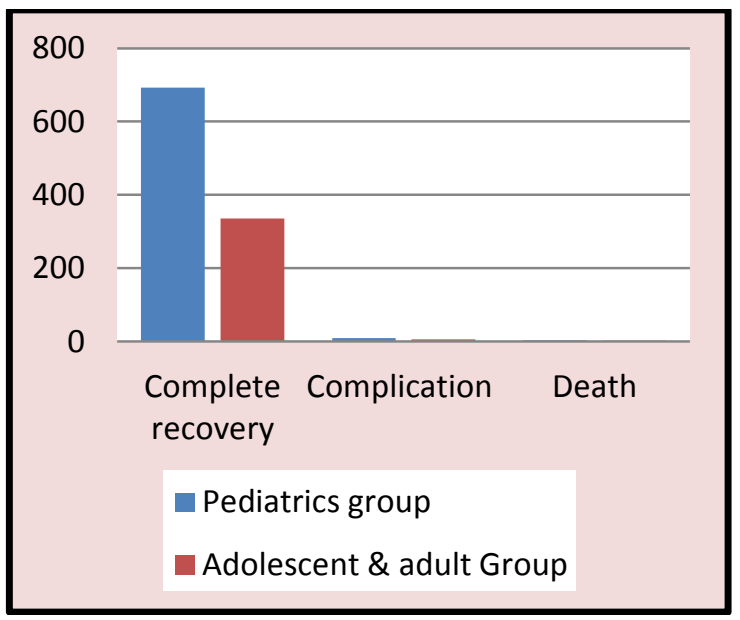

Fig (11): Outcome of poisoning among studied cases

\section{Discussion}

Knowledge of the epidemiology of poisonin $\mathrm{g}$ is crucial to emergency physicians. The $\mathrm{p}$ atternofpoisoning differsfrom one country to another and from one city to other within the same country and over time (6).

The present study was conducted on 1046 patients admitted to Kafr El Sheikh Governorate Hospitals with acute poisoning during the period starting from the first of January 2015 till the first of January 2017. They were examined and accompanied relative were interviewed.

421 patients are males (40.15\%) and 625 are females $(59.84 \%)$, with male to female ratio is 1: 1.2. The age of patients in this study ranged from 1 year to above 20 year with a mean of $6.61 \pm 4.98$ years for males and $9.13 \pm 5.63$ years for females.

In the current study,children under 6 years $\mathrm{r}$ epresented only $44.26 \%$. Theannual report of the PCC, Ain Shams in 2011 shows an appr oximate result with $23.9 \%$ children under the age of 7 years ${ }^{(7)}$. 
Children less than 5 years constituted (44.26\%), while adolescents (13- $\leq 19$ years) constituted $(17.87 \%)$. The least is demonstrated among above 30 year group $(6.40 \%)$.

The highest percentage of poisoned patients among female children wasless than 6 years $(41.6 \%)$. While among the highest percentage wasin adolescence $13-\leq 19$ years $(10.6 \%)$ with significant relation between sex and age where $\mathrm{P}<0.001$. (44.2\%) of poisoned patients were in the preschool group followed by patients in secondary school $(23 \%)$.

The current work revealed that, girls exceeded boys $(59.84 \%$ compared to $40.15 \%)$. In contrast, in Wu et $\boldsymbol{a l l}^{\mathbf{( 8 )}}$ study in Taiwan, the boys represented $(56.6 \%)$ while girls represented (43.4\%) of the poisoned cases.

The patients coming from urban regions $(68.64 \%)$ were more or less similar to those from rural regions $(31.35 \%)$ with no statistically significant relation between the residence group and sex or age.

In agreement with the study of Batra $\boldsymbol{e t} \boldsymbol{a l}{ }^{(\mathbf{9})}$ on Indian population demonstrated that the rural area showed higher incidence of poisoning compared to the urban area.

About half of the patients (54.68\%) were admitted during the night shift, followed by the morning shift $(31.16 \%)$, while the least number of patients were admitted during the afternoon shift (14.14\%).

In accordance with the present work, Eisenbach et $\boldsymbol{a l}^{\left({ }^{(\mathbf{1 0})}\right.}$ found a significant variation with the time of the day with a peak before midnight for both sexes .Yet, this study concerned with self- poisoning rather than other causes of poisoning. In addition, their mean ages were higher.

The highest number of patients were admitted during August (15\%) followed by July $(13.09 \%)$, while the least number of patients were admitted during December (3.7\%). The incidence of female poisoning was higher in all months of study except July. In contrast, Eisenbach $\boldsymbol{e t}$ al. ${ }^{(\mathbf{1 0})}$ demonstrated that no significant variation with the monthly or annual cycle was observed among self-poisoning cases.
A higher figure of $77.7 \%$ of accidental poisoning was reported by Yang $\boldsymbol{e t}$ al. ${ }^{(11)}$ in TaiwanandOzdogan $\boldsymbol{e t} \boldsymbol{a l}^{(\mathbf{1 2})}$ in southeast of Turkey.

Pharmacological agents, constituted the highest percentage of the poisoning (28.92\%), followed by Insecticides $(24.4 \%)$, household products $(20.45 \%)$, food poisoning $(12.5 \%)$ and animal poisoning $(8.03 \%)$.

Among males, the percentage of poisoning was higher compared to females in chlorax, insecticides, food poisoning, corrosives, animal poisoning $(24.3 \%, 14.9 \%, 8.7 \%, 6.5 \%, 2.5 \%$, 1.6 , and $0.4 \%$, respectively). However, the percentage of poisoning was higher among females in insecticides, analgesics, miscellaneous.

About 1027 patients (98.18\%) recovered completely, only $1.3 \%$ developed complications.

In the present study only 5 cases died with mortality rate $(0.47 \%)$.

Worldwide published case fatality rates of poisoning incidentsrange from as low as 0.07 in the USA in 2010, to up to $18.6 \%$ in $\operatorname{India}^{(\mathbf{1 3})}{ }^{(14)}$

The majority of cases stayed at the hospital (51.9\%), while (40.8\%) Discharged from ED and about $(7.2 \%)$ referred to nearest poison centers.

\section{Conclusion:}

The present study provided an important data to evaluate the magnitude of the problem of acute toxicity in Kafr El Sheikh Governorate. In addition, it may be a starting point to the evaluation of the problem in other governorates. Thus, a future work is needed to illustrate the magnitude of the problem allover Egypt. This can help in design of effective prevention measures.

From the results of the present study it can be concluded that;

1- Poisoning of children and adult constituted an important issue in Egypt.

2- $\quad$ Acute poisoningin Egypt involvesa v ariety of toxic agents

of whichpharmaceuticals, pesticides, household products and food poisoning predominated. 
3- The patients coming from urban regions were more or less similar to those from rural regions

4- The majority of cases of acute poisoning were accidental (78.01\%), followed by attempted suicide $(21.98 \%)$.

5- Accidental poisoning gradually decreases with increase of the age, while those who attempted suicidal poisoning increased with age.

6- Differences based on age category, sex, the types of toxic agents involved an $\mathrm{d}$ the outcomes of the poisoning incidents were noted.

7- $\quad$ The majority of cases recovered in all age groups with staying at the hospital for one day.

8- $\quad$ Overall mortality of poisoning islow.

\section{Recommendations}

Based on the present study, the following recommendations were proposed:

1 - Increasing attention about recording and documentation of poisoning cases in the hospitals' archives which help the researchers to perform statistical studies about the pattern of poisoning in the various governorates of Egypt which help the health authorities to develop a suitable health strategy for the diagnosis and treatment of poisoning.

2- The importance of development of community poisoning prevention program during putting the health strategies.

3 - The need to establish awareness and guide programs about poisoning in the mass media, especially for housewives on the causes and how to deal with cases of poisoning, as well as teach them ways to first aid measures in Occurrence of poisoning cases.

4- Assuring provision of antidotes and essential supplies for the treatment of poisoned patients, and arrangements for their rapid importation in the event of an emergency to treat patients effectively and quickly.

5- School curriculum program, poster contents, films and seminars about poisoning should be used to increase the community awareness about poisoning prevention and techniques for safe storage of poisons. Poisons must not be stored in cups or bottles previously contained soft drinks. Household products and medicines should be stored in closed cupboard away from the curious children.

6- New studies are essential in order to know the different spheres of reality for intoxication and poisoning accidents in children and adults.

7- Because of frequent poisoning with medications, the pharmaceutical companies should use child-proof packages for their products to prevent children' access to such items.

\section{References}

1. Irwin SR, Rippe JM ( 2008):Intensive Care Medicine .7th ed. Lippincott Williams \& Wilkins, pp55-1433.

2. Mansuy D (2013): Metabolism of xenobiotics: beneficial and adverse effects. https://www.ncbi.nlm.nih.gov/pubmed/236947 23

3. $\quad$ Singh B and Unnikrishnan B (2006) A profile of acute poisoning at Mangalore (South India) J Clin Med., 13: 112-116.

4. Wynn PM, Zou K, Young B, Hawkins A, Kay B and Kendrick D (2016): Prevention of childhood poisoning in the home: overview of systematic reviews and a systematic review of primary studies. Int $\mathrm{J}$ InjContrSafPromot., 23(1):3-28.

5. KivistöJE, Mattila VM, Arvola T, Paavola $M$ and Parkkari J(2008): Secular trends in poisonings leading to hospital admission among Finnish children and adolescents between 1971 and 2005. J Pediatr., 153:234-237.

6. Fernando $\quad \mathbf{R}(\mathbf{2 0 0 2})$ : The National Poisons Information Centre in SriLanka:the first ten years.JToxicolClinToxicol.,40:551-5.

7. El Masry MK, Tawfik HM (2013): 2011Annual Report of the Poison Control Centre of Ain Shams University Hospital, Cairo, Egypt. Ain Shams J Forensic MedClinToxicol.,20:10-7.

8. Wu AH,McKay C,Broussard LA,Hoffman RS,Kwong TC, Moyer TP et al. (2003): National academy ofc linical biochemistry laboratory medicine practice guidelines :recommendations for the use of laboratory tests to support poisoned patients who present to theemergency department. ClinChem.,49:357-79. 
9. Batra AK, Keoliya AN, Jadhav GU(2003): Poisoning: An Unnatural Cause of Morbidity and Mortality in Rural India. JAPI., 51: 955-9.

10. Eisenbach $\mathbf{C} 1$, Ungur $\mathbf{A L}$, Unger $\mathbf{J}$, Stremmel W, Encke J(2008): Admission to intensive care for parasuicide by selfpoisoning: variation by time cycles, climate and the lunar cycle. Psychiatry Res., 161: 17784

11. Yang CC, Wu JR Ong HC Kuo YP(1997):Deng JR Ger J. Children poisoning in Taiwan. Indian J Pediatr., 64: 469-83.

12. Ozdogan H, Davutoglu M, Bosnak M, Tutanc M, Haspolat K(2008):Pediatric poisonings in southeast of Turkey: epidemiological and clinical aspects. Hum Exp Toxicol., 27:45-8.

13. Bronstein AC, Spyker DA, Cantilena LR, Green JL, Rumack BH, Dart RC(2011):2010 Annual Report of the American Association of Poison Control Centers' National Poison Data System (NPDS): $28^{\text {th }} \quad$ AnnualReport. ClinToxicol(Phila);49:910-41.

14. Mc Laughlin JB(2004). Botulism type E outbreak associated with eating a beached whale, Alaska.EmergInfectDis.,10:1685-7. 